\title{
TRITIUM AND CARBON-14 IN RELEASES OF NUCLEAR REACTOR FACILITIES OF VARIOUS TYPES
}

\author{
E. Nazarov ${ }^{*}$, A. Ekidin, A. Vasilyev, M. Pyshkina, M. Vasyanovich
}

Institute of Industrial Ecology of Ural Branch of Russian Academy of Science, Ekaterinburg, Russia

\begin{abstract}
The production of electricity by European nuclear power plants with various types of reactor installations in the period from 1995 to 2017 was considered. For each nuclear power plant in Europe, the median specific emission indicators of tritium and carbon-14 $(\mathrm{GBq} / \mathrm{GWh})$ were calculated. Depending on these indexes, all stations were divided into 3 types: with the best, stable and the worst emission practices. A conservative estimate of the contribution of various reactor facilities to the activity of tritium and carbon-14 in the atmosphere was made. To assess the activity of tritium and carbon-14 entering the atmosphere as a result of emissions from the research nuclear reactor an experimental stand was developed.
\end{abstract}

Keywords: Atmosphere, nuclear power plants, emissions, assessment, carbon-14, specific indicator, tritium

\section{INTRODUCTION}

Currently nuclear power is an integral part of human life and accounts for more than $10 \%$ of the electricity produced in the world [1]. An important practical way to confirm the safe operation of nuclear power plants in the field of environmental protection is monitoring of radionuclide emissions into the atmosphere [2]. More than 90\% of European NPPs included tritium and carbon-14 in the emissions monitoring program [3] due to the main contribution to the population dose of these radionuclides [4] (Fig. 1).

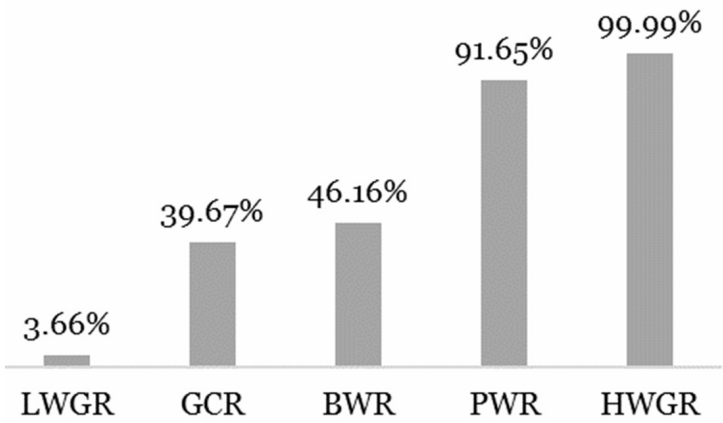

Figure 1. Total contribution of ${ }^{14} \mathrm{C}$ and $3 \mathrm{H}$ to effective dose from various nuclear installations

The aim of this paper is to assess the effluence and ingrowth of tritium and carbon into the atmosphere from releases of various types of reactor facilities.

\section{SOURCES OF TRITIUM AND CARBON-14}

\subsection{Natural sources}

Natural carbon-14 results from the reaction of the cosmic neutrons and nitrogen: ${ }^{14} \mathrm{~N}(\mathrm{n}, \mathrm{p})^{14} \mathrm{C}$. Other reactions: $\quad{ }^{15} \mathrm{~N}(\mathrm{n}, \alpha){ }^{14} \mathrm{C}, \quad{ }^{16} \mathrm{O}(\mathrm{p}, 3 \mathrm{p}){ }^{14} \mathrm{C}, \quad{ }^{17} \mathrm{O}(\mathrm{n}, \alpha){ }^{14} \mathrm{C}$, ${ }_{13} \mathrm{C}(\mathrm{n}, \gamma){ }^{14} \mathrm{C}$ contribute insignificantly due to the low reaction cross section and the low concentration of isotopes in the natural mixture of elements [5].

The total activity of natural carbon-14 in the atmosphere is about $1.4 \times 10^{17} \mathrm{~Bq}[6]$.

Natural tritium is constantly formed in the upper atmosphere due to the reactions: ${ }^{14} \mathrm{~N}(\mathrm{n}, \mathrm{T})^{12} \mathrm{C}$ and ${ }^{16} \mathrm{O}(\mathrm{n}, \mathrm{T})^{14} \mathrm{~N}$.

The total continuous activity of natural tritium is estimated to be from $1.85 \times 10^{18}$ to $4.50 \times 10^{18} \mathrm{~Bq}[7]$.

\subsection{Nuclear weapon testing}

One of the main sources of tritium and carbon-14 in the 2oth century was the nuclear weapon testing in the period from 1945 to 1980 . The total activity of tritium and carbon-14 released into the atmosphere was $2.4 \cdot 10^{20}$ and $2.5 \times 10^{17} \mathrm{~Bq}$, respectively $[5,8]$.

\subsection{Nuclear power plants}

For some nuclear power plants, tritium enters the atmosphere from both organized sources (ventilation system pipes) and unorganized sources (spray ponds and technological reservoirs) $[9,10]$. The main sources of tritium [11] are:

- triple fission of fuel nuclei;

- $(n, \gamma)$ reaction on the nuclei of deuterium located in the coolant - water;

*e.nazarov1005@gmail.com 
- neutron capture by boron and lithium nuclei located in the coolant (during boron regulation, correction of the water regime at nuclear power plants with pressurized water reactors - PWR) and in control rods;

- reaction ${ }^{3} \mathrm{He}(\mathrm{n}, \mathrm{p}) \mathrm{T}$ in the gas circuit (in the gas filling the graphite plenum) of light-water graphite reactors (LWGR);

- $(n, T)$ and (n,p) reactions of fast neutrons and nuclei ${ }^{14} \mathrm{~N},{ }^{6} \mathrm{Li},{ }^{10} \mathrm{~B},{ }^{4} \mathrm{Ca}$ and others, presented in various structural materials of the reactor.

During nuclear reactor operation, carbon-14 is mainly formed as a result of neutron activation reactions of various nuclei present in structural materials, fuel elements, moderator and coolant. The main sources of carbon-14 at nuclear power plants are [12]: fuel;

- triple fission of uranium and plutonium in nuclear

- reaction ${ }^{18} \mathrm{O}(\mathrm{n}, \mathrm{\alpha})^{14} \mathrm{C}$ (for water reactors);

- reactions ${ }^{13} \mathrm{C}(\mathrm{n}, \mathrm{\gamma})^{14 \mathrm{C}}$ and ${ }^{14} \mathrm{~N}(\mathrm{n}, \mathrm{p})^{14} \mathrm{C}$ (reactors with a graphite moderator);

\section{SPECIFIC EMISSION INDICATORS OF TRITIUM AND CARBON-14}

To assess the release of tritium and carbon into the atmosphere during the normal operation of a reactor facility, specific emission indicators were calculated. They allow to compare the emissions of different reactors, independently of their capacity. The specific indicators were obtained on the European Commission reporting information and annual emissions of European NPPs [13] and IAEA data on the electric energy generation [14]. The dimension of the indicator $\mathrm{GBq} / \mathrm{GWh}$ was chosen to demonstrate the scales of both emissions and energy production.

The analysis of specific indicators of tritium and carbon-14 emissions into the atmosphere was carried out for 76 European NPPs for the period 1995-2017. The sample size for annual specific emissions indexes, including the omissions in the database, amounted to 1243 and 1119 entries for tritium and carbon-14, respectively (Table 1 ).

Table 1. Statistical description of annual specific indexes of tritium and carbon-14 emissions by European NPPs from 1995 to 2017

\begin{tabular}{|c|c|c|}
\hline GBq/(GWh) & Tritium & Carbon-14 \\
\hline Average & 0.428 & 0.087 \\
Median & 0.076 & 0.035 \\
Lower quartile q1 & 0.034 & 0.024 \\
Upper quartile q3 & 0.161 & 0.075 \\
Minimum & $5.61 \cdot 10^{-4}$ & $5 \cdot 30 \cdot 10^{-4}$ \\
Maximum & 4.378 & 1.328 \\
Standard deviation & $\mathbf{0 . 2 7 3}$ & $\mathbf{0 . 1 6 2}$ \\
\hline
\end{tabular}

\subsection{Dynamics of specific indicators}

The hypothesis that the specific indicators are described by the normal distribution was rejected by the criteria of Shapiro-Wilk and Kolmogorov-Smirnov
$[15,16]$. For all indicators, a significant excess of the average over the median values is noticeable, which indicates a strong deviation of the probability distributions of the obtained data from the normal curve. In this regard, it was decided to use median specific emission indicators, since the median is less sensitive to statistical emissions, in contrast to the average. The dynamics of median specific indicators is shown in Figures 2, 3.

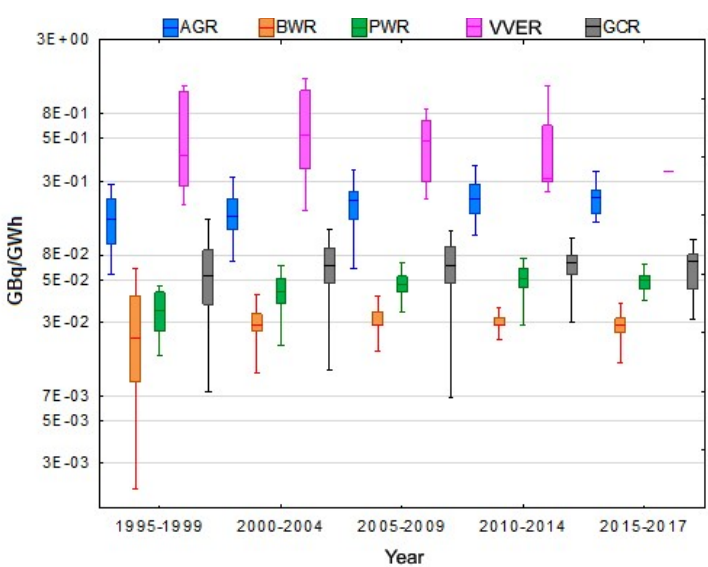

Figure 2. Median specific indicators of tritium discharges from European NPPs from 1995 to 2017

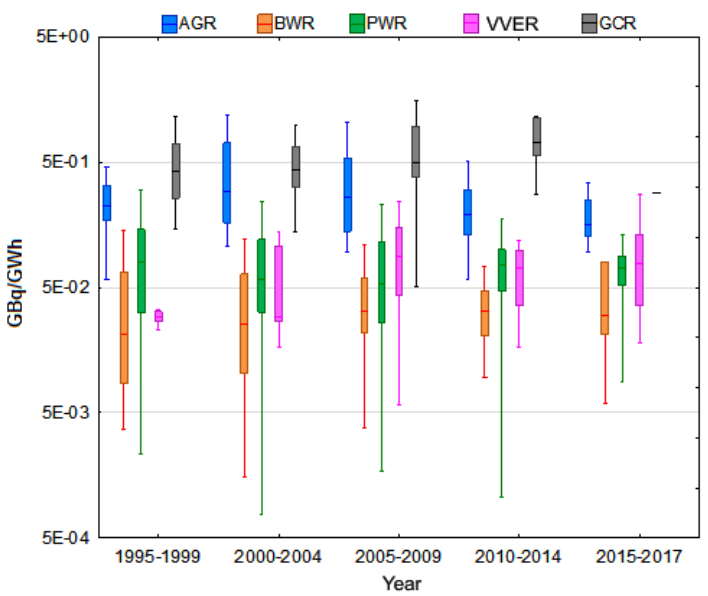

Figure 3. Median specific indicators of carbon-14 discharges from European NPPs from 1995 to 2017

As seen from Figures 2-3, gas-cooled reactors (GCR) and their second generation, advanced gascooled reactors (AGR), have the largest specific indicators of tritium and carbon emissions. Currently there is no NPP with an old-type gas-cooled reactor operating in Europe. The last GCR nuclear power plant, Wylfa (UK), was decommissioned in 2015. For the AGR, a decrease in the specific indicators of tritium emission into the atmosphere is generally noticeable, while the carbon-14 emission indicators tend to increase. 
The significance of temporary linear trends in specific indicators was estimated using Spearman's rank coefficients (Table 2), and the significance level of the trend was 0.05 [17]. In Table 2, N - number of observations, $\mathrm{R}$ - Spearman criterion.

Table 2. The results of the assessment of linear trends in the dynamics of specific indicators of tritium and carbon-14 emission by European nuclear power plants from 1995 to 2017

\begin{tabular}{|c|c|c|c|c|c|}
\hline \multirow{7}{*}{$3 \mathrm{H}$} & $\begin{array}{c}\text { Type } \\
\text { of NF }\end{array}$ & $\mathrm{N}$ & $\mathrm{R}$ & $\mathrm{p}$-value & Trend \\
\hline \multirow{6}{*}{ AGR } & 152 & -0.215 & 0.0076 & Decrease \\
& BWR & 202 & 0.148 & 0.0349 & Increase \\
& GCR & 62 & 0.256 & 0.0443 & Increase \\
& PWR & 727 & 0.040 & 0.2776 & None \\
& VVER & 100 & 0.190 & 0.0577 & None \\
\cline { 2 - 6 } & ALL & 1243 & -0.014 & 0.6201 & None \\
\hline \multirow{7}{*}{${ }^{14 C} \mathrm{C}$} & AGR & 152 & 0.342 & $1.6 \cdot 10^{-5}$ & Increase \\
& BWR & 178 & 0.107 & 0.1533 & None \\
& GCR & 66 & -0.071 & 0.5735 & None \\
& PWR & 616 & -0.028 & 0.4851 & None \\
& VVER & 107 & 0.310 & 0.0011 & Increase \\
\cline { 2 - 6 } & ALL & 1119 & -0.130 & $1.3 \cdot 10^{-5}$ & Decrease \\
\hline
\end{tabular}

\subsection{Best, stable and worst practices}

The calculation of the average ranks $\left(\mathrm{R}_{\mathrm{i}, \mathrm{j}}\right)$ according to Equation 1 made it possible to divide all European nuclear power plants into 3 categories: with the best, stable and worst practice of tritium and carbon-14 emission. The quartile values are shown in Table 1. Table 3 shows the number of nuclear power plants in each category.

$$
R_{i, j}=\left\{\begin{array}{c}
1, \text { if } \mathrm{Q}_{i, j} \leq q 1 \\
2, \text { if } q 1<\mathrm{Q}_{i, j} \leq q 3 \\
3, \text { if } \mathrm{Q}_{i, j}>q 3
\end{array}\right\}
$$

Table 2. The number of European nuclear power plants by groups with the best, stable and worst emission practices of tritium and carbon-14

\begin{tabular}{|c|c|c|c|c|c|c|}
\hline \multirow{2}{*}{$\begin{array}{c}\text { Type } \\
\text { of RF }\end{array}$} & \multicolumn{2}{|c|}{$\begin{array}{c}\text { Best } \\
\text { practices }\end{array}$} & \multicolumn{2}{c|}{$\begin{array}{c}\text { Stable } \\
\text { practices }\end{array}$} & \multicolumn{2}{c|}{$\begin{array}{c}\text { Worst } \\
\text { practices }\end{array}$} \\
\cline { 2 - 7 } & $3 \mathrm{H}$ & ${ }^{14} \mathrm{C}$ & $3 \mathrm{H}$ & ${ }^{14} \mathrm{C}$ & $3 \mathrm{H}$ & ${ }^{14} \mathrm{C}$ \\
\hline AGR & - & - & 3 & - & 4 & 7 \\
\hline BWR & 9 & - & 4 & 10 & - & 3 \\
\hline GCR & - & - & - & - & 4 & 4 \\
\hline PWR & 7 & 18 & 30 & 17 & 3 & 2 \\
\hline VVER & 1 & - & 5 & 7 & 1 & - \\
\hline
\end{tabular}

The best practice category is expected to be dominated by reactors with the lowest specific tritium and carbon-14 emission indicators: boiling water reactors - BWR (69\% of all European BWRs) and pressurized water reactors - PWR (49\% of all European
PWRs), respectively. At three nuclear power plants with PWR: Isar 1, Krümmel, Philippsburg (all Germany), the specific indicator of tritium emission from 1995 to 2017 did not exceed 0.034 GBq/GWh (q1 quartile value). For carbon-14, the same result was shown by Trillo NPP (Spain).

In the category with stable practice, for tritium emissions, NPPs with PWR type reactors $(75 \%$ of all European NPPs of this type) are predominantly represented, while for carbon-14 emissions these are BWR reactor facilities (77\% of all European BWRs).

The Worst Practices category for both tritium and carbon-14 are mainly presented by GCR and their second generation - AGR. These types of reactor installations are not widespread and are present only in the UK.

\subsection{Conservative estimate of tritium and carbon-14 releases into the atmosphere}

According to the information described earlier, specific indicators of tritium and carbon-14 releases were calculated for each type of the reactor facility. Using these indicators and electricity generated data by NPPs since 1954 a conservative estimate of tritium and carbon-14 intake into the atmosphere was made. The conservative estimate does not consider the decomposition of nuclides and their distribution in compartments. In Figures 4-5, the comparison of different sources of tritium and carbon-14 is presented.

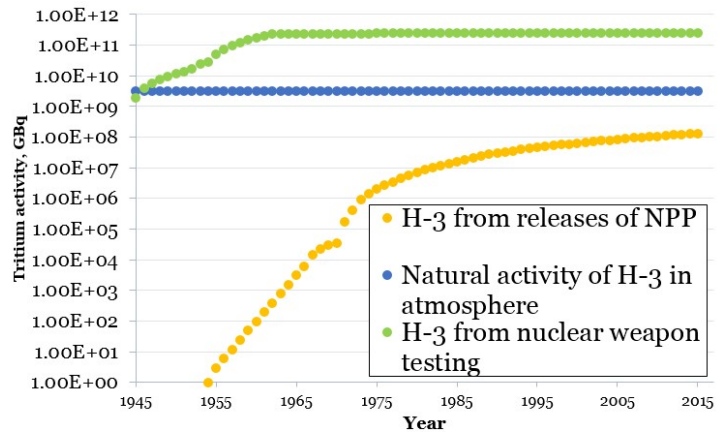

Figure 4. Conservative estimate of tritium releases from various sources

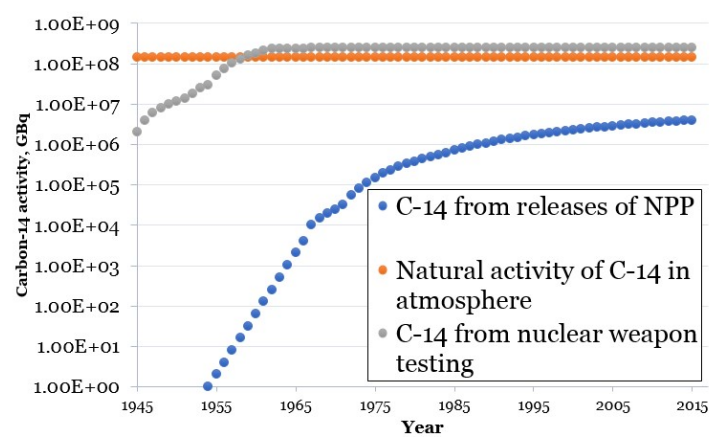

Figure 5. Conservative estimate of carbon-14 releases from various sources 
4. EXPERIMENTAL ASSESSMENT OF TRITIUM AND CARBON-14 RELEASES INTO THE ATMOSPHERE

Studies of gas-aerosol mixture emissions in ventilation systems of Russian nuclear power plants are presented in [18]. The obtained results demonstrate that the contribution of tritium and carbon-14 as a dose-forming nuclide can reach $52 \%$ and $98 \%$ respectively.

\subsection{Sources of tritium and carbon-14 in research} nuclear reactors

As an object of the research, the IVV-2M research nuclear reactor, which is an analog of VVER, was chosen. The nuclear installation is located at the Institute of Nuclear Materials, Zarechny. It was launched in 1966. Thermal capacity is 15 MW [19].

The presence of tritium in the emissions of IVV-2M is due to the following factors:

- a priori presence of tritium in distilled water;

- the reaction of the interaction of neutrons and boron while using boron control: ${ }^{10} \mathrm{~B}(\mathrm{n}, 2 \mathrm{\alpha})^{3} \mathrm{H}$;

- the reaction of the interaction of neutrons and lithium- 6 formed as a result of "poisoning" of beryllium blocks in the reactor core [20]: ${ }^{6} \mathrm{Li}(\mathrm{n}, \alpha)^{3} \mathrm{H}$;

- ternary fission.

Carbon-14 is presented in the emissions of IVV-2M due to three factors:

- the interaction of neutrons and oxygen-17, present in the coolant (moderator) - water: ${ }^{17} \mathrm{O}(\mathrm{n}, \alpha){ }^{14} \mathrm{C}$;

- the commercial production of carbon-14 in the form of aluminum nitride (AlN) [21];

- ternary fission.

\subsection{Experimental stand}

In order to confirm the data obtained earlier, an experimental stand was developed which allows sampling of tritium and carbon-14 and their further analysis by liquid scintillation spectrometry. To study the possible dynamics of tritium and carbon-14 emission during normal operation of reactor, the experimental assessment of their activity in the emissions of a research nuclear reactor was carried out with various reactor operation modes.

The functional scheme of the stand is shown in Figure 6.

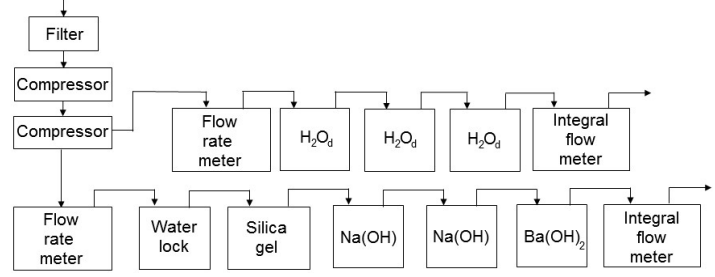

Figure 6. Functional scheme of the experimental stand

The stand is connected to a standard gas-air mixture sampling system, which is formed during the operation of the reactor installation. An aerosol filter is installed to exclude the influence of beta-active aerosols on the measurement result of the samples. Two compressors are used as an air blower. At the inlet of both lines, a float flow meter is installed to control the instantaneous air flow. The air flow recommended for this sampling method is $0.6 \mathrm{l} / \mathrm{min}$.

\subsection{Results}

The sampling of tritium in the form of HTO from the gas-air mixture is carried out via barbotage using three vials with distilled water. The total flow rate of the pumped gas-air mixture is determined using an integral meter installed at the end of the sampling line. Tritium volumetric activity is analyzed using a scintillation spectrometer.

Carbon-14 was sampled in the form of $\mathrm{CO}_{2}$. Water lock is needed to avoid tritium intake into the vials with $\mathrm{NaOH}$, which is absorber for $\mathrm{CO}_{2} . \mathrm{Ba}(\mathrm{OH})_{2}$ is an indicator that reaction (2) is proceeding.

$$
\mathrm{NaOH}+\mathrm{CO}_{2}=\mathrm{NaCO}_{3}+\mathrm{H}_{2} \mathrm{O}
$$

The results of measuring the volume activity of tritium and carbon-14 in the emissions of the research nuclear reactor are presented in Figures 7-8.

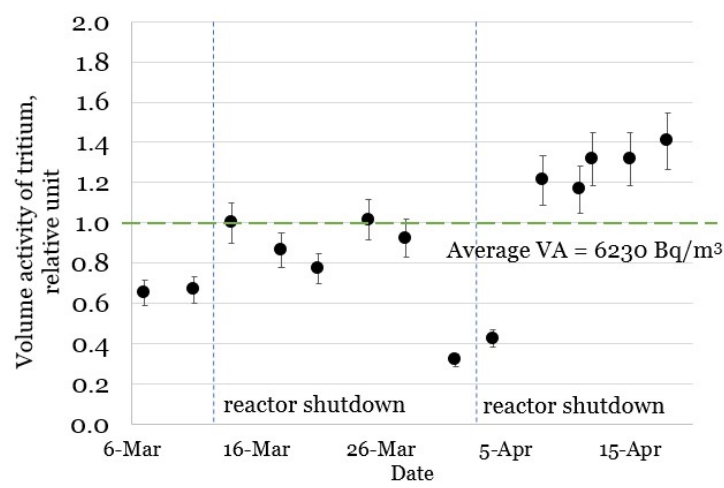

Figure 7. The results of measuring the volume activity of tritium in the releases of "IVV-2M"

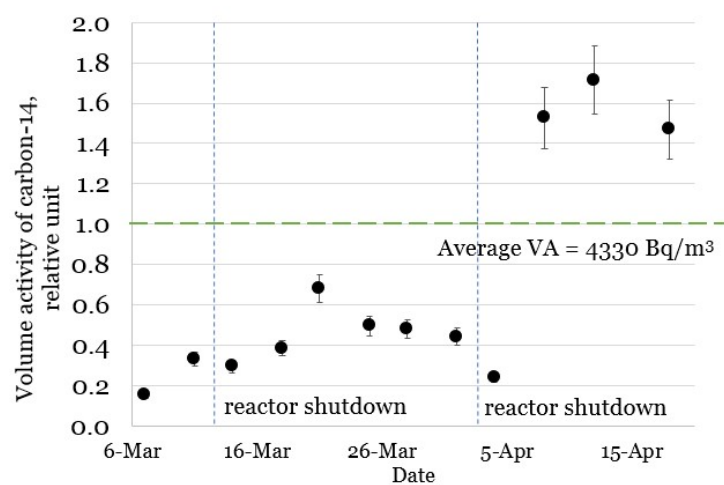

Figure 8 . The results of measuring the volume activity of carbon-14 in the releases of "IVV-2M" 
As can be seen from Figure 7, a decrease in the volume activity of tritium is observed during the shutdown of the reactor. This is due to the fact that the evaporation of HTO is less intense due to the fuel bundles being less heated in the absence of a chain reaction. The increase in the volume activity of carbon-14 in Figure 8 may be caused by the changes in the reactor core.

\section{CONCLUSION}

The analysis of the European Commission and IAEA data demonstrated that the lowest specific indicators of tritium and carbon-14 emissions are characteristic for BWR and PWR, respectively. The largest specific emission indicators for both radionuclides were showed by gas-cooled reactors (GCR and AGR).

The growth trend of specific carbon-14 emission indicators for AGR can be explained by the large age of stations with this reactor type (about 40 years) and, as a result, the degradation of technical components, as well as structural materials. In general, for specific indicators of carbon-14 emissions, a downward trend is noticeable. The increase in specific indicators of tritium emission is characteristic for gas-cooled reactors of the old type; however, currently there is no operating power plant with GCR (old type) in Europe.

A conservative estimate of the influx of tritium and carbon into the atmosphere showed that the global contribution of releases from the world's nuclear power plants of during the normal operation of the plants amounts to several percent of the natural activity of these radionuclides in the atmosphere. The main source determining the activity of tritium and carbon14 in the second half of the 2oth century were nuclear weapons tests from 1945 to 1980 . Currently the activity of these radionuclides in the atmosphere is close to atmospheric activity in the period before the tests.

The estimated volumetric activity of tritium and carbon-14 in the emissions of the IVV-2M research nuclear reactor allows to calculate the effective dose at the critical point. For tritium the effective dose is 6.34 $\mu \mathrm{Sv} /$ year, for carbon-14 $-2.19 \mu \mathrm{Sv} /$ year. The obtained effective doses are insignificant and lower than the effective doses from the natural radiation background.

Acknowledgements: The paper was supported by the Ural Branch of Russian Academy of Science Project 18-11-2-2.

\section{REFERENCES}

1. Indicators for Nuclear Power Development, Nuclear Energy Series No. NG-T-4.5, IAEA, Vienna, Austria, 2015, pp. 3- 4 . Retrieved from: https://wwwpub.iaea.org/MTCD/Publications/PDF/Pub1712 web.p $\underline{\mathrm{df}}$ Retrieved on: May 2, 2018
2. Environmental and Source Monitoring for Purposes of Radiation Protection, Safety Guide No. RS-G-1.8, IAEA, Vienna, Austria, 2005, pp. 5 - 13.

Retrieved from:

https://www-

pub.iaea.org/MTCD/publications/PDF/Pub1216 web. pdf

Retrieved on: May. 2, 2018

3. A. A. Ekidin, M. H. Zhukovskii, M. E. Vasyanovich, "Identification of the main dose-forming radionuclides in NPP emissions," Atomic energy, vol. 120, no. 2, pp. $134-137$, Jun. 2016. DOI: $10.1007 / \mathrm{s} 10512-016-0107-\mathrm{x}$

4. М.Д. Пышкина, “Определение основных дозообразующих нуклидов в выбросах AЭC PWR и ВВЭР," Биосферная совместимость: человек регион, технологии, но. 2 (18), стр. 98 - 107, 2017. (M. D. Pyshkina, "The determination of main doseforming nuclides in NPP PWR and VVER releases," Biosphernaya sovmestimost: Chelovek, Region, Technologii, no. 2 (18), pp. 98 - 107, 2017.)

Retrieved from: https://elibrary.ru/download/elibrary 29435089 67 17971.pdf Retrieved on: May 2, 2018

5. Е. И. Назаров, А. А. Екидин, А. В. Васильев, “Оценка поступления углерода-14 в атмосферу, обусловленного выбросами АЭС," Известия высших учебных заведений. Физика, том 61, но. 12 - 2, стр. $67-73,2018$

E. I. Nazarov, A. A. Ekidin, A. V. Vasiljev, "Assessment of the atmospheric carbon-14 caused by NPP emissions," Izvestiya Vuz. Fizika, vol. 61, no. 12 - 2, pp. $67-73,2018$.

Retrieved from:

https://elibrary.ru/item.asp?id=36888653

Retrieved on: May 2, 2018

6. Carbon-14 and the environment, Radionuclide Fact Sheet, IRSN, Paris, France, 2010.

Retrieved from:

https://www.irsn.fr/EN/Research/publications-

documentation/radionuclides-

sheets/environment/Documents/Carbone_UK.pdf Retrieved on: Nov. 23, 2017

7. Investigation of the Environmental Fate of Tritium in the Atmosphere, Rep. INFO-0792, CNSC, Ottawa, Canada, 2009.

Retrieved from:

https://nuclearsafety.gc.ca/pubs catalogue/uploads/In vestigation of Environmental Fate of Tritium in $t$ he Atmosphere INFO-0792 e.pdf

Retrieved on: Jan. 25, 2019

8. Д.Д. Дмитриевич, А.А. Екидин, “Оценка поступления трития в окружающую среду от выбросов АЭС," Биосферная совместимость: человек, регион, технологии, но. 1 (21), стр. 88 - 96, 2018.

(D. D. Desyatov, A. A. Ekidin, "Evaluation of tritium's entry into the environment from nuclear power plants' emissions," Biosphernaya sovmestimost: Chelovek, Region, Technologii, no. 1 (21), pp. 88 - 96, 2018.)

Retrieved from:

https://elibrary.ru/download/elibrary_34959688 709 98513.pdf

Retrieved on: Mar. 2, 2019

9. А.А. Екидин, К. Л. Антонов, М. В. Жуковский, “Оценка загрязнения атмосферы тритием при испарении воды с поверхности промышленных водоёмов," Вопросы радиационной безопасности, но. 3 (67), стр. 3 - 10, 2012.

(A. A. Ekidin, K. L. Antonov, M. V. Zhukovskii, "Assessment of tritium air pollution due to water 
evaporation from the surface of industrial reservoirs," Voprosy Radiatsionnoy Bezopasnosti, no. 3 (67), pp. 3 - 10, 2012.)

Retrieved from:

https://elibrary.ru/item.asp?id $=18037186$

Retrieved on: Mar. 12, 2019

10. А. А. Екидин и др., "Оценка поступления трития в атмосферу из брызгальных бассейнов балаковской АЭС в холодный период," Ядерная и радиационная безопасность, но. 3 (85), стр. 35 - 46, 2017.

(A. A. Ekidin et al., "Assessment of Tritium Escape into Atmosphere from the Spray Ponds of the Balakovo NPP in Cold Seasons," Yadernaya $i$ Radiatsionnaya Bezopasnost', no. 3 (85), pp. 35 - 46, 2017.)

Retrieved from:

https://elibrary.ru/download/elibrary_30297016 1772 0315.pdf Retrieved on: Mar. 2, 2019

11. А. Г. Цикунов, В. В. Алексеев, С. В. Забродская, К. В. Тыклеева, "Источники образования трития в реакторах типа БН,” Вопросы атомной науки и техники. Серия: ядерно-реакторные константы, но. 1, стр. $74-78,2015$.

(A. G. Tsikunov, V. V. Alekseev, S. V. Zabrodskaya, K. V. Tykleeva, "Sources of tritium production in bntype reactors," Voprosy Atomnoy Nauki i Tekhniki. Seriya: Yaderno-Reaktornyye Konstanty, no. 1, pp. $74-78,2015$.

Retrieved from:

https://vant.ippe.ru/images/pdf/2015/1-9.pdf

Retrieved on: Mar. 2, 2019

12. X. Hou, "Tritium and ${ }^{14} \mathrm{C}$ in the Environment and Nuclear Facilities: Sources and Analytical Methods," J. Nucl. Fuel Cycle Waste Technol., vol. 16, no. 1, pp. 11 - 39, Mar. 2018.

DOI: 10.7733/jnfcwt.2018.16.1.11

13. Radioactive Discharges Database, European Commission, Brussels, Belgium, 2016.

Retrieved from:

http://europa.eu/radd/nuclideDischargeOverview.dox? pageID=NuclideDischargeOverview

Retrieved on: Jan. 5, 2018

14. Power Reactor Information System, IAEA, Vienna, Austria.

Retrieved from: https://pris.iaea.org/PRIS/home.aspx

Retrieved on: Jan. 5, 2018

15. S. S. Shapiro, M. B. Wilk, "An analysis of variance test for normality (complete samples)," Biometrika, vol. 52, no 3/4. pp. $591-611$, Dec. 1965.

Retrieved from:

http://www.bios.unc.edu/ mhudgens/bios/662/2008f all/Backup/wilkshapiro1965.pdf

Retrieved on: Mar. 10, 2019
16. Encyclopedia of Mathematics: Kolmogorov-Smirnov test, The European Mathematical Society, Helsinki, Finland, 2012.

Retrieved from:

https://www.encyclopediaofmath.org/index.php/Kolm ogorov-Smirnov test

Retrieved on: Mar. 10, 2019

17. Encyclopedia of Mathematics: Spearman coefficient of rank correlation, The European Mathematical Society, Helsinki, Finland, 2012.

Retrieved from:

https://www.encyclopediaofmath.org/index.php/Spear man coefficient of rank correlation

Retrieved on: Mar. 10, 2019

18. M. Vasyanovich et al., "Special monitoring results for determination of radionuclide composition of Russian NPP atmospheric releases," Nucl. Eng. Technol., vol. 51, no. 4, pp. 1176 - 1179, Jul. 2019.

DOI: 10.1016/j.net.2019.02.010

19. И. М. Русских, "Исследовательский реактор ИВВ2М", Атомная энергия, том 121, но. 4, стр. 183 - 186, 2016.

(I. M. Russkikh, "Research Reactor IVV-2M," Atomnaya Energiya, vol. 121, no. 4, pp. $183-186$, 2016.)

Retrieved from:

https://elibrary.ru/item.asp?id=27201105

Retrieved on: Apr. 10, 2019

2о. И. В. Прозорова, "Влияние отравления бериллиевых блоков на нейтронно-физические характеристики реактора ИВГ.1М,” Известия томского политехнического университета. Инжиниринг георесурсов, том. 326, но. 2, стр. 148 155, 2015.

(I. V. Prozorova, "The effect of poisoning of beryllium blocks on the neutron-physical characteristics of the IVG.1M reactor," Izvestiya Tomskogo Politekhnicheskogo Universiteta. Inzhiniring Georesursov, vol. 326, no. 2, pp. 148 - 155, 2015.) Retrieved from: http://www.lib.tpu.ru/fulltext/v/Bulletin TPU/2015/v 326/i2/15.pdf Retrieved on: Apr. 11, 2019

21. С. Б. Злоказов и др., "Методические и инженерные подходы к производству изотопов на реакторе ИВВ2M", Атомная энергия, том 121, но. 4, стр. 227 232, Окт. 2016.

(S. B. Zlokazov et al., "Methodological and engineering approaches to the production of isotopes at the IVV-2M reactor," Atomnaya Energiya, vol. 121, no. 4, pp. 227 232, Oct. 2016.)

Retrieved from:

https://j-

atomicenergy.ru/index.php/ae/article/view/461

Retrieved on: Apr. 11, 2019 